\title{
Upland burning and grazing as strategies to offset climate-change effects on wetlands
}

\author{
Owen P. McKenna • David A. Renton • David M. Mushet • Edward S. DeKeyser
}

Received: 8 May 2020/Accepted: 15 December 2020/Published online: 11 January 2021

(C) This is a U.S. government work and not under copyright protection in the U.S.; foreign copyright protection may apply 2021

\begin{abstract}
Wetland ecosystems perform a multitude of services valued by society and provide critical habitat for migratory birds and other wildlife. Despite their importance, wetlands have been lost to different local, regional, and global drivers. Remaining wetlands are extremely sensitive to changing temperature and precipitation regimes. Management of grassland areas in wetland catchments may be an effective strategy for counteracting potentially negative impacts of climate change on wetlands. Our objective was to estimate the effects of climate changes on wetland hydrology, and to explore strategies for increasing surface-water inputs to wetlands. We coupled a field study with process-based simulation modeling of wetland-water levels. We found that climate change could decrease the number of wetlands that hold ponded water during the waterfowl breeding season by $14 \%$ under a hot wet scenario or $29 \%$ under a hot dry scenario if no upland-management actions were taken.
\end{abstract}

Supplementary information The online version of this article (https://doi.org/10.1007/s11273-020-09778-1) contains supplementary material, which is available to authorized users.

O. P. McKenna $(\bowtie) \cdot$ D. M. Mushet

U.S. Geological Survey, Northern Prairie Wildlife

Research Center, Jamestown, ND, USA

e-mail: omckenna@usgs.gov

D. A. Renton - E. S. DeKeyser

School of Natural Resource Sciences, North Dakota State

University, Fargo, ND, USA
Upland burning reduced pond losses to 9\% (hot wet) and $26 \%$ (hot dry). Upland grazing resulted in the smallest loss of ponded wetlands, $6 \%$ loss under the hot-and-wet scenario and $22 \%$ loss under the hot-anddry scenario. Overall, water inputs could be increased by either burning or grazing of upland vegetation thereby reducing pond losses during the waterfowl breeding season. While field results suggest that both grazing and burning can reduce the vegetative structure that could lead to increases in runoff in grassland catchments, our model simulations indicated that additional actions may be needed for managers to minimize future meteorologically driven water losses.

Keywords Prairie-pothole wetlands · Migratory waterfowl · Grassland management $\cdot$ Climate change . PHyLiSS

\section{Introduction}

Non-floodplain, depressional wetlands provide critical habitat for migratory birds and other wildlife, in addition to performing a multitude of other services valued by societies. Despite their local, regional, and global significance, these wetland ecosystems have been lost to many anthropogenic pressures and are considered to be "vulnerable waters" (Creed et al. 2017). The ecohydrological functioning of remaining non-floodplain, depressional wetlands is extremely 
sensitive to perturbations in temperature and precipitation (McKenna et al. 2017). One continentally important region for non-floodplain, depressional wetlands that is currently experiencing both climatechange and land-use-change pressures is the North American Prairie Pothole Region (PPR) (McKenna et al. 2019).

The PPR encompasses $\sim 770,000 \mathrm{~km}^{2}$ of the North American continent, spanning five US states (Iowa, Minnesota, South Dakota, North Dakota, Montana) and three Canadian provinces (Alberta, Manitoba, Saskatchewan) (Dahl 2014; Smith et al. 1964). The US portion of the PPR contains an estimated 2.6-million depressional wetland basins (Dahl 2014). The wetlands of the PPR provide a multitude of services to society including nutrient cycling, sediment reduction, and stormwater retention (Gleason et al. 2008). These wetlands also provide critical breeding habitats that support North American migratory-bird populations, especially waterfowl (Niemuth et al. 2014). At the landscape level, annual distribution and number of breeding waterfowl are strongly correlated to the number of wetlands that contain ponded water during the month of May in a given year, hereafter referred to as "May ponds" (Niemuth and Solberg 2003).

Breeding season wetland inundation is highly variable year-to-year and smaller wetlands are directly dependent on snowmelt (Shook and Pomeroy 2012). Snowmelt dynamics are dependent on antecedent soil moisture that is recharged during summer and fall rainstorm events (McKenna et al. 2017). The primary hydrological output from prairie-pothole wetlands is evapotranspiration. The PPR is located in an area of the continent with a semi-arid climate where potential evapotranspiration is greater than precipitation (Hayashi et al. 2016).

A recent nearly three-decade-long wet period in the US portion of the PPR has resulted in increased precipitation inputs during summer and early fall months with little change in winter precipitation (McKenna et al. 2017). This recent shift to wetter meteorological conditions is much longer than past oscillations between dry and wet modes that occurred throughout the twentieth century (Winter and Rosenberry 1998). Increased summer precipitation may increase the number of prairie-pothole wetlands that contain ponded water, but the timing of these events could be out of sync with the needs of migratory-birds that use the wetlands to breed in the spring. Extreme summer precipitation events are also expected to persist in the future due to climate change (Ballard et al. 2014), but the impact of these large precipitation events on prairie-pothole wetland hydrology may be minimized by increased temperature-driven evapotranspiration.

Precipitation is more difficult to predict than temperature due to high spatial and temporal variability. Projected climate-model means under moderate increases in emissions from Representative Concentration Pathway (RCP) 4.5 project precipitation for the Northern Great Plains region could increase by as much as $10 \%$ or decrease by as much as $5 \%$ from historical levels (USGRCP 2017). The potential impact of future climate change on prairie-pothole wetlands ranges between wetlands being much drier (Johnson et al. 2010) or moderately wetter (McIntyre et al. 2019) in the future. Upland management practices may help maintain ponded water important to breeding waterbirds.

Global climate models are all in agreeance that average temperatures of Earth's surface will increase through the end of this century (USGRCP 2017). Evapotranspiration rates are also generally higher than water inputs for prairie-pothole wetlands in the region and will increase if the warmer temperatures associated with climate change are realized (Hayashi et al. 2016). However, temperature increases associated with climate change are expected to vary regionally. Multi-model averages from moderate emissions scenario RCP 4.5 project that the Northern Great Plains of the USA may experience temperature increases of around $4{ }^{\circ} \mathrm{C}$ by the end of the twenty-first century (USGRCP 2017). Mean annual air temperatures of the PPR have already increased by $1{ }^{\circ} \mathrm{C}$ over the past century (Millett et al. 2009). The impacts of increased temperatures and changes in precipitation in the PPR on wetland hydrology can also be enhanced or dampened by upland land management, because these wetlands are dependent on surface-water runoff inputs.

Waterfowl are typically associated with wetlands, but the majority of waterfowl in the PPR nest in adjacent uplands (Niemuth et al. 2014). Avian reproductive success is highly variable, but nesting success of many species of grassland-nesting birds, including waterfowl, typically increases with the amount of grass in the landscape due to reductions in predator 
densities associated with food crops and grassland fragmentation (Stephens et al. 2005). The management of grasslands surrounding prairie-pothole wetlands can impact the amount of snowmelt and summer runoff that makes it from uplands to prairie-pothole wetlands (Voldseth et al. 2007). Due to the effects of land cover on runoff and evapotranspiration, it is believed that land-cover changes resulting from upland management actions can be used to offset negative effects of climate change on wetland hydrology (Voldseth et al. 2009). Grazing and burning upland plant communities, two common land-management techniques, can increase runoff and alter evapotranspiration regimes by altering vegetative structure and soil properties in uplands surrounding wetlands (Bremer and Ham 1999; Cronshey et al. 1986; Renton et al. 2015). Less is known about how grazing and burning impacts snow accumulation in uplands that contributes to critical spring ponding of prairie-pothole wetlands. The combined effect of climate change and land management is expected to impact different types of prairie-pothole wetlands in different ways.

The classification of prairie-pothole wetlands is based on water permanence and diagnostic plant communities that form vegetative zones reflective of differing water depths (Stewart and Kantrud 1971). Class II and III, temporarily and seasonally ponded, wetlands produce abundant invertebrate populations in early spring and are typically ponded throughout May, thereby providing ideal habitat for breeding waterfowl (Winter 2003). These wetlands make up an estimated $90 \%$ of all intact, prairie-pothole wetlands (Dahl 2014). Class II and III wetlands typically have small, shallow basins, shallow ponds, and hydrology that is especially sensitive to changes between wet and dry years. Throughout the PPR, climate strongly influences the number of prairie-pothole wetlands that contain ponded water on the landscape, as well as the duration and depth of water ponded in those wetlands (McKenna et al. 2017). It is because of the smaller size and shorter hydroperiods that Class II and III wetlands are expected to be more vulnerable to changes in climate than the larger, more permanently ponded Class IV and V wetlands (Johnson and Poiani 2016; Johnson et al. 2010; Larson 1995; Niemuth et al. 2010; Poiani et al. 1996).

Our objective was to estimate the sensitivity of prairie-pothole wetland hydrology to changes in precipitation, temperature, and land-management practices. We also aimed to estimate how spatial and temporal wetland ponding dynamics would be affected under extreme climate-change and landmanagement scenarios. Specifically, we had three research questions: (1) How do upland-management practices impact snow accumulation? (2) How sensitive is the hydrology of prairie-pothole wetlands to changes in precipitation, temperature, and upland landcover? (3) Can changes to upland management regime alter impacts of climate change on prairiepothole wetland hydrology?

\section{Methods}

Our research approach combined field and modeling experiments. First, we measured the effect of grazing and burning on snow accumulation through a multiyear, multi-catchment, field experiment and incorporated observed effects of upland management on snow into a simulation modeling exercise. Next, we used a mechanistic systems-model to simulate ponded-water depth through time in a typical prairie-pothole wetland. We used this modeling approach to analyze the sensitivity of wetland ponding to changes in precipitation, temperature, and land-management strategies separately. Finally, we upscaled our model to a sub-section of the PPR with a high density of breeding waterfowl to estimate the effect of different climate-change and land-management scenarios on the number of May ponds, which is known to correlate strongly to the number of breeding waterfowl in a given year (Niemuth and Solberg 2003).

\section{Study area}

The experimental wetlands and catchments used to test the effect of grazing and burning on snow accumulation are within the US Fish and Wildlife Service's (USFWS) Woodworth Study Area (WSA) on the Missouri Coteau of central North Dakota at latitude $47^{\circ} 8^{\prime} \mathrm{N}$ and longitude $99^{\circ} 14^{\prime} \mathrm{W}$. The WSA landscape is typical of the PPR, i.e., characterized by irregular terrain with numerous interspersed wetlands. The WSA was purchased by the USFWS in 1964 and has been managed as a research site since that time. Prior to federal ownership, parts of the study area had been cultivated (Williams and Austin 2014). These 
areas have since been reseeded to perennial grass and forb cover. The low-permeability soils of the studied wetlands are of glacial till origin (Omodt et al. 1968). The climate of the area is typical of a continental region with long, cold winters and short, warm summers. Monthly temperature averages range from $2.8{ }^{\circ} \mathrm{C}$ in January to $37.8{ }^{\circ} \mathrm{C}$ in July. Annual precipitation averages about $43 \mathrm{~cm}$ but is highly variable with periods of drought and deluge. However, the region is currently (2020) experiencing a wet period that has persisted since 1993 (McKenna et al. 2017).

Field hydrology data were also collected at the Cottonwood Lake Study Area (CLSA), which is located on the eastern portion of the Northwestern Glaciated Plains ecoregion (Omernik 1987) in Stutsman County, North Dakota. The CLSA is a long-term research site that consists of 16 individual depressional wetlands that make up a wetland complex monitored by the US Geological Survey (Mushet and Euliss 2012). Research at the CLSA began in 1966 and includes studies of the site's hydrology, water chemistry, weather, and vegetation, in addition to aquaticmacroinvertebrate, amphibian, and bird communities. Hydrology, water chemistry, and ecosystem data collected at the CLSA can be found at the Missouri Coteau Wetland Ecosystem Observatory (https:// www.sciencebase.gov/catalog/item/

52f0ffd9e4b0f941aa181fc6). All wetland modeling for this study focused on "Wetland T8". Wetland T8 is located near the highest part of the study area above the groundwater table. T8 contains shallow-marsh vegetation throughout its central zone during normal and wet years, which is typical of Class III wetlands (Stewart and Kantrud 1971). During dry years wetmeadow vegetation becomes dominant in the center of the wetland (Winter 2003).

Upland management practices impact on snow accumulation

The application of two management strategies were tested across nine, Class III, wetland catchments located at the WSA. This field study took place during 2014 and 2015. 2014 was a pre-treatment year and snow measurements were taken in all experimental catchments in late February 2015, before treatments were applied. Temporary electric fences were installed surrounding each wetland catchment to exclude them from grazing that took place on the management unit in 2015. All the catchments had been managed in a similar manner since purchased by the USFWS in 1964. The primary management strategy of the wetland catchments from 1964 to 2013 was non-use with occasional prescribed burning (Williams and Austin 2014). Four of the catchments were cultivated prior to federal ownership and have since been planted into a mix of perennial grasses and legumes (Meyer 1985). Three replicates of two management strategies (treatments; grazing and fall burning) were randomly assigned to six wetland catchments. The remaining three catchments received no treatment and served as controls (i.e., no management). Grazing took place from mid-May to late-July 2015. The grazing treatment was applied across the entire management unit and thus the temporary electric fences were removed from these wetland catchments to allow access to cattle. Prescribed burns were conducted in early November 2015 for the three wetland catchments receiving the prescribed-burn treatment. In total, three wetland catchments were grazed, three were burned, and three were controls. Snow sampling occurred again in late February 2016 to account for net snow accumulation that effectively contributes to spring runoff into down-stream wetlands.

Snow sampling with 60-mm-diameter acrylic tubing occurred every two meters along two, 30-m transects along the north and south facing back-slope position, and every two meters along two 20-m transects in the toe-slope position of the upland catchment. Snow was also sampled in the wetlands every two meters along two $20-\mathrm{m}$ transects in the wetmeadow zone, and at ten random locations in the shallow-marsh zone of each wetland. Each core was weighed in the field with a portable scale. Snow depth and weight measurements were used to calculate Snow Water Equivalent (SWE; Eq. 1), i.e., the amount of water contained within a given volume of snow. As snowfall amounts differed for each year of the study a proportional SWE was calculated to compare the effects across years. Proportional SWE was calculated by dividing the SWE measured within the study wetlands by a baseline measurement of the total snowfall during the winter season (McKenna et al. 2020b).

$S W E=$ Snow Density $\times$ Snow Depth

We compared mean SWE and their associated 95\% confidence intervals before and after treatments were 
applied to test the effects of the applied treatments. We estimated confidence intervals by sampling from a simulated distribution. Measurements were compared for each study wetland before and after each treatment. If a $95 \%$ confidence interval straddled zero it was assumed that there was no detected effect, and if the 95\% confidence intervals did not straddle zero then an effect was detected with the mean representing the size of the effect. Confidence intervals provide a measure of uncertainty and effect size in terms of the measured units and therefore provide more relevant information than hypothesis testing (Gardner and Altman 1986; Johnson 1999).

We also conducted sampling of vegetation and litter at the same locations where we sampled snow depth (McKenna et al. 2020b). In November 2014 Pretreatment plant community attributes were measured in each wetland catchment using modified cover-class estimates of plant cover in $0.25-\mathrm{m}^{2}$ quadrats. Litter depth was also recorded at the center of each quadrat to estimate average litter depth at each landscape position. Fifty, ten-pin, point frames were also used along the backslope of the catchment area to get an estimate of basal cover and bare ground prior to treatment. All sampling was repeated in November 2015 after treatments had been applied to quantify management induced change.

\section{Wetland-hydrology model description}

We modeled hydrology in CLSA wetland T8 using the Pothole Hydrology-Linked System Simulator (PHyLiSS), which is a daily-timestep systems model designed for exploring the effects of climate and land-use on prairie-pothole wetland ecosystems (McKenna et al. 2018). Inputs used to model the wetland pond include daily average temperature, daily precipitation, and wetland basin morphometry (Mushet et al. 2016). Precipitation in the form of rain either falls directly on the wetland or the upland with surface runoff being calculated with the Soil Conservation Service runoff curve number $(\mathrm{CN})$ method (Cronshey et al. 1986). A "dry, normal, or wet" CN is used for the given land cover is used to calculate runoff depending on the total 5-day cumulative precipitation. When the antecedent precipitation is less than $3.5 \mathrm{~cm}$ then the "dry" $\mathrm{CN}$ is used, when the antecedent precipitation is between 3.5 and $5.0 \mathrm{~cm}$ then the "normal" $\mathrm{CN}$ is used, and when the antecedent precipitation is greater than $5.0 \mathrm{~cm}$ then the "wet" $\mathrm{CN}$ is used. When air temperatures are lower than $0{ }^{\circ} \mathrm{C}$, precipitation accumulates as snow, which melts when the ten-day mean air temperature is above $2{ }^{\circ} \mathrm{C}$. Snow that accumulates over the wetland area goes directly into ponded water, while the fraction of meltwater from upland snow that enters the wetland as runoff is dependent on the antecedent soil moisture in October of the preceding year as represented by the Palmer Hydrologic Drought Index (Palmer 1965). Water losses include evapotranspiration, shallow groundwater loss via infiltration, and fill-and-spill from wetland to downstream waterways. Evapotranspiration is calculated using the Hamon Equation for potential evapotranspiration (Hamon 1961). Shallow groundwater losses are accounted for using the equation from Huang et al. (2013). Spill from the basin occurs when the water level of the wetland pond reaches a low point in the divide between adjacent catchments. More detailed descriptions and validations of the PHyLiSS model can be found in (McKenna et al. 2018).

We input all the morphometric (Mushet et al. 2017) and atmospheric (Menne et al. 2012) inputs to PHyLiSS for wetland T8 over a 35-year period (1982-2016) and compared simulated wetland pond stage to observed field measurements (Fig. 1). These inputs came from weather-station data, bathymetric surveys of CLSA wetlands and lidar-derived catchment delineations (Mushet et al. 2017). Temperature and precipitation data were collected at CLSA with missing values being replaced by a weighted average of three nearby weather stations as part of the National Weather Service Global Historical Climatology Network (Menne et al. 2012). The runoff $\mathrm{CN}$ is based off of a soil's hydrologic soil group and ground-cover type (Cronshey et al. 1986). The soils of Wetland T8's catchment belong to the soil hydrologic group 'B' (Soil Survey Staff 2016) and the ground-cover type was continuous grass protected from grazing. Thus, the runoff $\mathrm{CN}$ used to represent the historic conditions under dry, normal, and wet conditions in our model simulations were 36, 58, 76 (Cronshey et al. 1986). We performed all analyses and visualization found throughout this paper using RStudio version 1.1.419 (R-Core-Team 2017). 


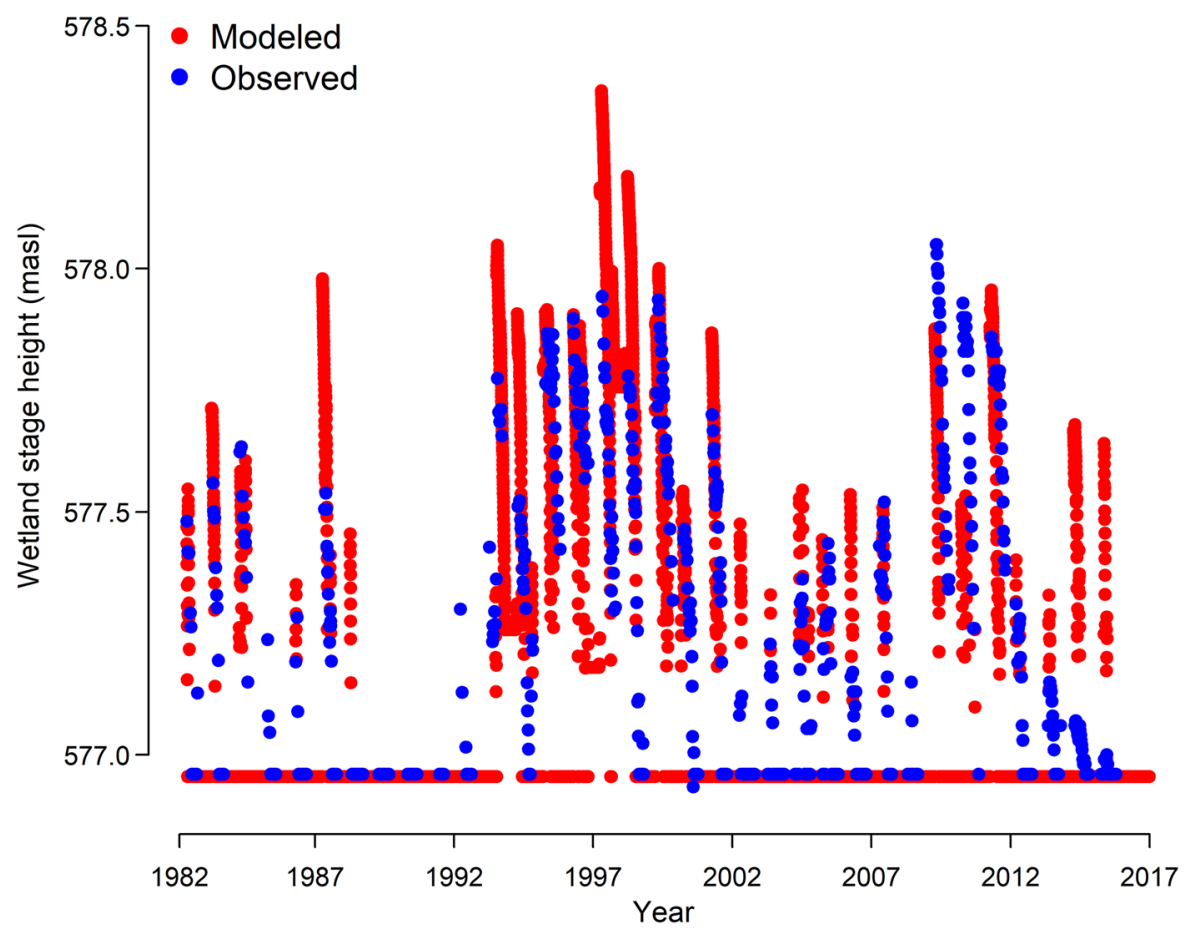

Fig. 1 Simulated (red) and observed (blue) water levels (meters above sea level) of Wetland T8 of the Cottonwood Lake Study Area (1982-2016)

Wetland hydrology sensitivity to climate and landcover change

To test the sensitivity of the model to changes in climate and land cover, we altered various inputs within expected thresholds. In total, we adjusted temperature, precipitation, and the runoff $\mathrm{CN}$. Temperature was adjusted in two different ways, (1) a general increase in temperature of +2 and $+4{ }^{\circ} \mathrm{C}$ across all the temperature data and (2) a seasonally adjusted temperature based on the differences between 55-year mean monthly temperature trends from three nearby North Dakota weather stations (Jamestown, Minot, Grand Forks) (1907-1961) and (1962-2016) (Table 1). These monthly temperature changes were to account for predicted seasonal variation in temperature expected for the region (Meehl et al. 2004; Ojima and Lackett 2002). We then calculated a relative weight for each month by taking the difference for each month and dividing by the mean of all the monthly differences. We multiplied the relative weight for each month by 2 and 4 for each temperature change scenario and added or subtracted that value from the daily mean air temperature record to reflect
Table 1 Historical temperature trends for North Dakota by month from 1907 to 2016

\begin{tabular}{lc}
\hline Month & $\begin{array}{c}\text { Temperature change } \\
\text { from 1907 to 2016 }\left({ }^{\circ} \mathrm{C}\right)\end{array}$ \\
\hline January & +2.61 \\
February & +4.11 \\
March & +1.41 \\
April & +1.27 \\
May & +1.93 \\
June & +1.30 \\
July & +0.80 \\
August & +1.70 \\
September & +1.08 \\
October & +0.35 \\
November & -0.04 \\
December & +1.63 \\
\hline
\end{tabular}

those monthly-adjusted differences in temperature (Table S1). These trend data were then averaged to equal $\mathrm{a}+2$ and $+4{ }^{\circ} \mathrm{C}$ change over a year and then added to the original temperature data according to the month. 
Precipitation changes are based on the projections for precipitation trends for the region of a $-5 \%,+5 \%$, and $+10 \%$ change in precipitation (IPCC 2013). Changes to the runoff CN were based off changes to ground cover associated with different management practices. If ground cover is between 50 and $75 \%$, the runoff $\mathrm{CN}$ for dry, normal, and wet periods were adjusted to $48.8,69,83.7$ for hydrologic soil group B, and if ground cover is less than $50 \%$ the CN was adjusted to $61.2,79,89.6$ for the same hydrologic soil group (Cronshey et al. 1986). We then assessed the response of hydroperiod (number of days during growing season that a wetland pond contained water), the average water depth in meters, and the maximum water depth in meters.

Modeling wetland hydrology under climate change and land-management scenarios

We independently modeled the effects of grazing and burning as mitigation strategies under wet and hot, and dry and hot climate-change scenarios for a Class III, seasonally ponded, prairie-pothole wetland using PHyLiSS. The two climate-change scenarios included monthly adjusted temperatures for a mean annual increase in temperature of $4{ }^{\circ} \mathrm{C}$. The wet-hot scenario included $10 \%$ increase in mean annual precipitation distributed evenly across historical daily precipitation data in addition to the $4{ }^{\circ} \mathrm{C}$ warming (NOAA 2016). The dry-hot scenario included a $5 \%$ decrease in mean annual precipitation distributed evenly across historical daily precipitation data in addition to the $4{ }^{\circ} \mathrm{C}$ warming (NOAA 2016). The wet-hot and dry-hot scenarios were run first without any management (Normal $\mathrm{CN}=58$ ) occurring in the uplands. Then, we modeled the climate-change scenarios with the effects of either grazing or burning.

The grazing scenario represents a season-long (May-August) grazing regime at a moderate-to-heavy grazing intensity. This grazing scenario would reduce vegetation cover and prevent a mulch layer from forming. A normal runoff $\mathrm{CN}$ of 79 was used to approximate runoff of a moderate-to-heavy grazing scenario, approximately 1.0 animal unit months per hectare (Cronshey et al. 1986). We found that grazing at this level did not alter snow distributions at the WSA (Fig. 2). The burning scenario represents a 5-year fall burn interval, which is a conservative recommended rate for the Northern Great Plains of the US (Higgins

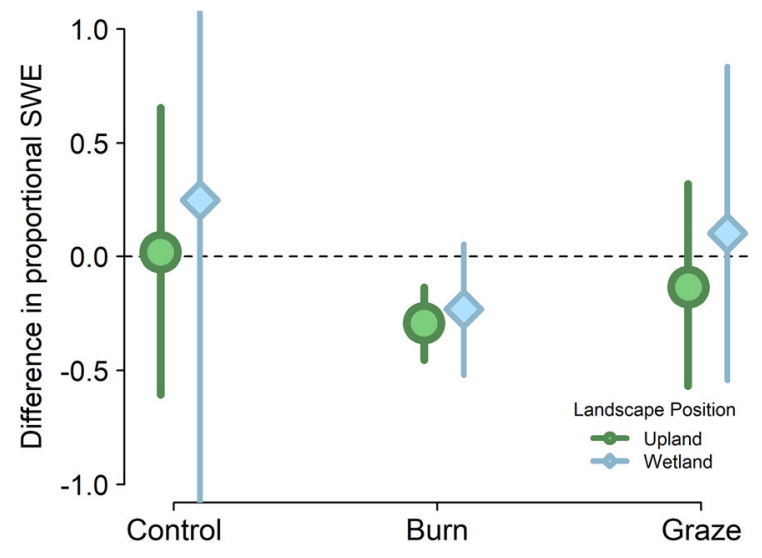

Fig. 2 Comparison of means with $95 \%$ confidence intervals of differences in snow water equivalent (SWE) between different years and treatments. Dashed line represents the effect line, points and solid lines represent mean effect and 95\% confidence intervals. Green symbols represent the values for the upland area of the catchments and blue symbols represent values for the wetland portion of the catchments

1989). The effects of burning on the runoff $\mathrm{CN}$ are not well studied for the region in question; therefore, we estimated a normal runoff $\mathrm{CN} 80$ for the first year after a burn. This scenario was based off of previous research on the effects of burning on the runoff $\mathrm{CN}$ in other regions (Yochum and Norman 2015). The temporal effects of burning have received very little attention; thus, we have estimated that the effects of a burn on the normal runoff $\mathrm{CN}$ would linearly decrease by 5.5 each year following the fire until year 5 when the runoff curve returned to the baseline value (Normal $\mathrm{CN}=58$ ) (Table $\mathrm{S} 2$ ). We also reduced upland snow cover by $29.2 \%$ the winter following the burn based on empirical findings from our field study (Fig. 2). Because the wetland snow was not impacted when the upland was burned (Fig. 2) we assumed the upland snow losses were moved out of the wetland catchment and not included in the wetland water budget.

Scaling up to regional estimate of ponded wetlands

We used simple linear regression to first determine the best-fit relationship between PHyLiSS output and empirical counts of ponded wetlands occurring during the waterfowl breeding season. Low-altitude aerial surveys of waterfowl and ponded wetlands in the PPR (Waterfowl Breeding Population and Habitat Survey) are conducted by the US Fish and Wildlife Service 
each May (Dahl 2014). These field-based May pond counts have formed the basis of much prior work on waterfowl population trends in the PPR (Niemuth and Solberg 2003). We used regression analysis and Akaike's information criterion to determine if modeled values of average or maximum May wetland depth from PHyLiSS could be used to predict May ponds from 1982 to 2015. The May pond values were from stratum 46 (Fig. 3) (https://migbirdapps.fws. gov), which CLSA is located centrally within as displayed in McKenna et al. (2017). Stratum 46 is divided roughly in half between two ecoregions of North Dakota called the Missouri Coteau and the Drift Prairie (Fig. 3). The Missouri Coteau portion of stratum 46 contained $85 \%$ of the area classified as nonriverine water area in 2017 (Fig. 3). The uplands of the drift prairie are $92 \%$ cropland and $8 \%$ grasslands. The uplands of the Missouri Coteau are 35\% croplands and $65 \%$ grasslands.

We evaluated how May pond numbers in stratum 46 could change in the future using the established best-fit relationship between PHyLiSS model output and annual May ponds. We converted the maximum May ponded wetland depth PHyLiSS output to an estimate of annual May ponds. The annual May pond value we used was adjusted to be represent only the $\sim 35 \%$ of wetland basins estimated to be embedded in grassland catchments in stratum 46 (Table 2). We estimated future changes for three scenarios where all grasslands are either dormant with no management, grazed, or burned. We used analysis ready Landsatderived land cover data to estimate upland land cover in stratum 46 portion of North Dakota to assess the percent of wetland basin that are currently surrounded by grassland uplands that could be impacted by
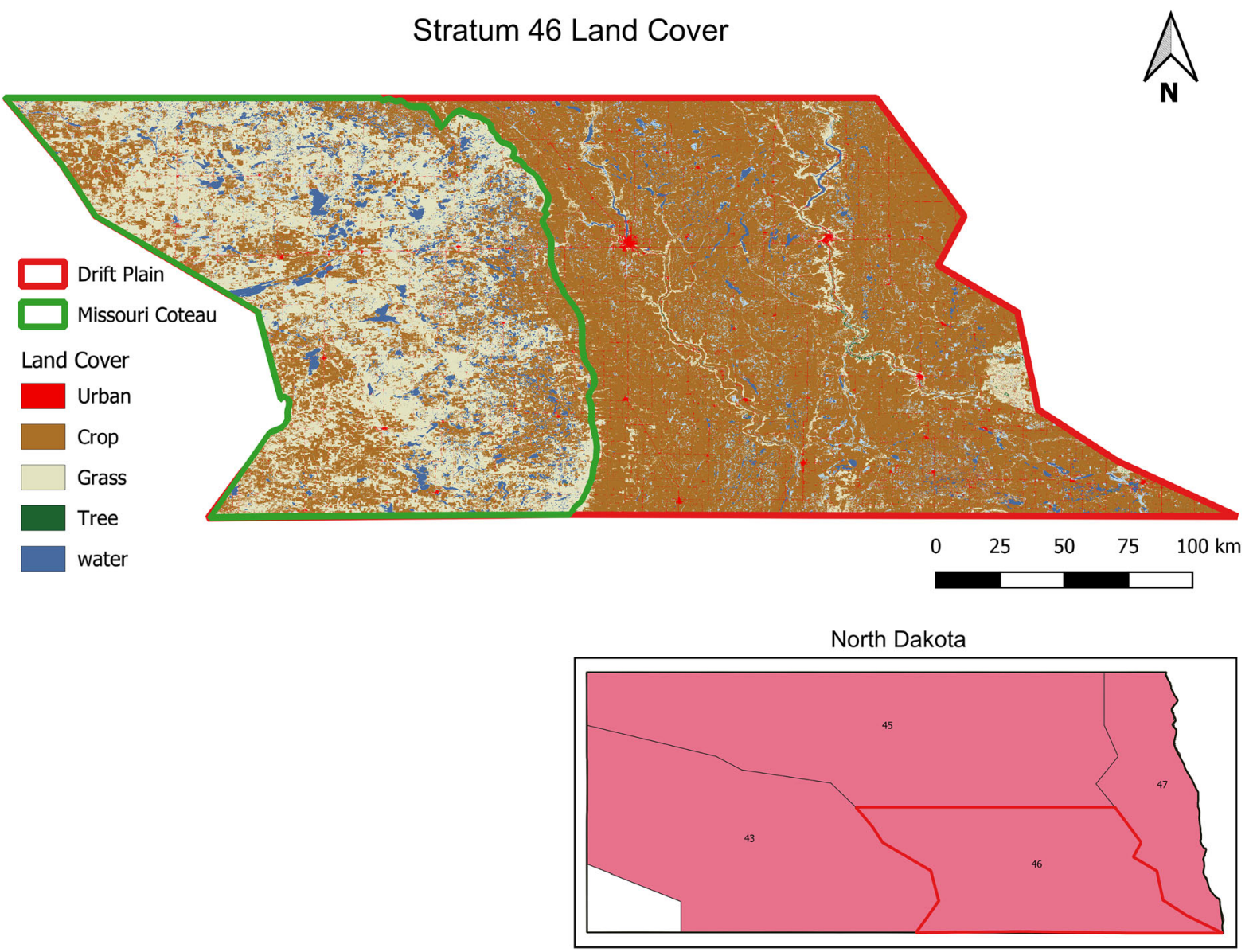

Fig. 3 30-m resolution land cover map from 2017 with spatial extent of the US Fish and Wildlife Service Waterfowl Breeding Population and Habitat Survey Strata in North Dakota, USA 
Table 2 Descriptive statistics from 30-m resolution 2017 land cover spatial data for US Fish and Wildlife Service Waterfowl Breeding Population and Habitat Survey Strata in North Dakota, USA Stratum 46

\begin{tabular}{llll}
\hline Ecoregion & $\begin{array}{l}\text { Total wetland } \\
\text { basins }\end{array}$ & $\begin{array}{l}\text { \% Upland } \\
\text { grassland }\end{array}$ & $\begin{array}{l}\text { Maximum grassland- } \\
\text { embedded wetlands basins }\end{array}$ \\
\hline Missouri Coteau & 117,366 & 65 & 76,287 \\
Drift Prairie & 131,573 & 8 & 10,526 \\
\hline
\end{tabular}

grazing or burning management practices. We used gridded 30-m resolution land cover data from 2017 classified by the USGS Land Change Monitoring, Assessment, and Projection (LCMAP) initiative (Sohl et al. 2019). LCMAP has been found $\sim 95 \%$ accurate at identifying land cover classes (Zhou et al. 2020). These data are publicly available at https://doi.org/10. 5066/P9YQMNHF.

\section{Results}

Upland management practices impact on snow accumulation

Snow water equivalent in the grazing and no-management plots did not significantly change between year one and year two (Fig. 2). A fall prescribed burn significantly reduced SWE by $29.2 \%$ over the upland portion of the catchments and had no significant effect on the wetland portion of the catchment (Fig. 2). These empirical results were used to adjust model parameters in PHyLiSS to better depict the effect of burning on SWE one year after a burn.

Grazing and prescribed burning were found to influence the vegetation structure within wetland catchments (McKenna et al. 2020a). Burning reduced height in the upland vegetation by $67 \%(12 \mathrm{~cm})$ from 18 to $6 \mathrm{~cm}$. Grazing decreased the height of the upland vegetation by $20 \%(4 \mathrm{~cm})$ from 20 to $16 \mathrm{~cm}$. Treatments had similar effects on the litter depth within the wetland catchments. The mean litter depth was reduced in burn catchments by $81 \%$ from 6.4 to $1.2 \mathrm{~cm}$. The mean litter depth was reduced in grazed catchments by $62 \%$ from 6.1 to $2.3 \mathrm{~cm}$. Basal litter cover was also reduced at different rates by burning and grazing. The burn treatment reduced basal litter cover by $22.8 \%$ along the backslope of the catchments. Grazing only reduced basal litter cover by $1.3 \%$.
Model validation

We demonstrated that over a 35-year period there was a significant linear relationship between the modeled and observed water levels in the Class III wetland "T8" ( $\left.\mathrm{R}^{2}=0.6, \mathrm{p}<0.01, \beta=0.9\right)$. The daily model fit explained $\sim 60 \%$ of the variance in the observed ponded-water depth (Fig. 1). Qualitatively, the model also simulated initial water input in the spring of each year and the seasonal draw down during the summer months. The model also correctly simulated a period of drought (mid-1980's to early-1990) in which Wetland T8 remained dry, and a period of deluge (early-1990's to early-2000) in which historically high-water levels were observed at the site (Fig. 1). McKenna et al. (2017) also demonstrated that the deluge period from 1993-present has been driven by increases in May, July, and October precipitation that is delivered as liquid precipitation and runoff and not snow, whereas pre-1993 wetland hydrology was dominated by water inputs from spring snowmelt only. Therefore, the model shows now difference in performance when the water inputs are mainly snowmelt or warm season precipitation-runoff.

Prairie-pothole wetland hydrology sensitivity to climate and land-cover change

We found that altering model inputs within expected limits produced a variety of responses to the PHyLiSS model output (Table 3). The increase in mean annual temperature and the monthly adjusted temperature increase resulted in similar decreases to growing season hydroperiod, average water depth, and max water depth. The hydroperiod was slightly more sensitive to the monthly temperature increases and the water depth variables were slightly more sensitive to the general temperature increases. The growing season hydroperiod and average depth were sensitive to a $10 \%$ increase in precipitation causing wetlands to 
Table 3 Model sensitivity to changes in (A) climate and (B) runoff curve number (CN) under "normal" 5-day cumulative precipitation between 3.5 and $5 \mathrm{~cm}$

\begin{tabular}{|c|c|c|c|c|c|c|c|c|}
\hline & Historical & $+2{ }^{\circ} \mathrm{C}$ & $+4{ }^{\circ} \mathrm{C}$ & $\begin{array}{r}+2{ }^{\circ} \mathrm{C} \\
\text { adjusted } \\
\text { monthly }\end{array}$ & $\begin{array}{l}+4^{\circ} \mathrm{C} \\
\text { adjusted } \\
\text { monthly }\end{array}$ & $\begin{array}{l}-5 \% \\
\text { precip }\end{array}$ & $\begin{array}{l}+5 \% \\
\text { precip }\end{array}$ & $\begin{array}{l}+10 \% \\
\text { precip }\end{array}$ \\
\hline \multicolumn{9}{|l|}{ (A) } \\
\hline Hydroperiod (days) & 56.21 & $\begin{array}{l}46.50 \\
(-17.3)\end{array}$ & $\begin{array}{l}46.33 \\
(-17.6)\end{array}$ & $\begin{array}{l}46.00 \\
(-18.2)\end{array}$ & $\begin{array}{l}45.62 \\
(-18.8)\end{array}$ & $\begin{array}{l}46.89 \\
(-16.6)\end{array}$ & $\begin{array}{l}66.71 \\
(+18.7)\end{array}$ & $\begin{array}{l}84.00 \\
(+49.4)\end{array}$ \\
\hline Average water depth (m) & 0.15 & $\begin{array}{l}0.08 \\
(-46.7)\end{array}$ & $\begin{array}{l}0.05 \\
(-66.7)\end{array}$ & $\begin{array}{l}0.09 \\
(-40.0)\end{array}$ & $\begin{array}{l}0.05 \\
(-66.7)\end{array}$ & $\begin{array}{l}0.12 \\
(-20.0)\end{array}$ & $\begin{array}{l}0.18 \\
(+20.0)\end{array}$ & $\begin{array}{l}0.28 \\
(+86.7)\end{array}$ \\
\hline Max water depth (m) & 1.41 & $\begin{array}{l}1.25 \\
(-12.7)\end{array}$ & $\begin{array}{l}1.20 \\
(-14.9)\end{array}$ & $\begin{array}{l}1.37 \\
(-2.8)\end{array}$ & $\begin{array}{l}1.22 \\
(-13.5)\end{array}$ & $\begin{array}{l}1.37 \\
(-2.8)\end{array}$ & $\begin{array}{l}1.44 \\
(+2.1)\end{array}$ & $\begin{array}{l}1.57 \\
(+11.3)\end{array}$ \\
\hline (B) & (B) & \multicolumn{2}{|c|}{ Normal runoff CN 69} & \multicolumn{5}{|c|}{ Normal runoff $\mathrm{CN} 79$} \\
\hline Hydroperiod (days) & 56.21 & $\begin{array}{l}62.93 \\
(+12.0)\end{array}$ & \multicolumn{5}{|c|}{74.17} & \\
\hline Average water depth (m) & 0.15 & $\begin{array}{l}0.18 \\
(+20.0)\end{array}$ & \multicolumn{5}{|c|}{0.53} & $(+253.3)$ \\
\hline Max water depth (m) & 1.41 & $\begin{array}{l}1.42 \\
(+0.7)\end{array}$ & \multicolumn{6}{|c|}{1.46} \\
\hline
\end{tabular}

Values represent averages over a 35-year period from 1982-2016. Numbers in parenthesis represent the percent deviation from the historical wetland T8 model

be wetter $\sim 50 \%$ longer during the growing season and on average $\sim 90 \%$ deeper. Increases in the runoff $\mathrm{CN}$, not surprisingly, caused the greatest increases to average wetland water depths by more than $250 \%$ from 0.15 to $0.53 \mathrm{~m}$. Overall, the average water depth was the measure most sensitive to changes in climate and runoff $\mathrm{CN}$, while maximum water depth was the least sensitive.

Wetland hydrology responses to climate change and land-management scenarios

Simulated water levels and hydroperiod were overall much lower under the climate-change scenarios in the absence of upland management (Fig. 4, Table 4). The simulated wetland dried up 16 days sooner on average under the hot dry scenario and remained wetter an average 4 days longer under the hot wet scenario. Despite the longer hydroperiod under the hot wet scenario, the average and maximum water depths were reduced in both climate-change scenarios. Grazing and burning had different efficacies for increasing growing season hydroperiods and water depths (Table 4). Grazing had the most substantial impact on wetland hydrology under the different climatechange scenarios. Under the hot dry scenario hydroperiod water depths were still lower than the historical climate but grazing increased hydroperiod by $10 \%$ and average water depths by $\sim 20 \%$ when compared to the no management scenario. Under the hot wet scenario grazing caused gains across all hydrology metrics for the growing season. The 5-year burning management scenario increased the hydroperiod by $8 \%$ and average water depths by $7 \%$ when compared to the no-management scenario.

Climate change and land management impacts on regional estimate of ponded wetlands

We found a significant positive linear relationship between the maximum pond depth in the month of May and the observed number of May ponds from the same year (1982-2015) (Fig. 5). We used this best-fit regression model May ponds $/ 10,000=$ modeled $\max$ May wetland pond depth $(\mathrm{m}) * 7.692+4.837$ to estimate how May ponds in stratum 46 could be affected by different climate and land-management scenarios using PHyLiSS model output. 


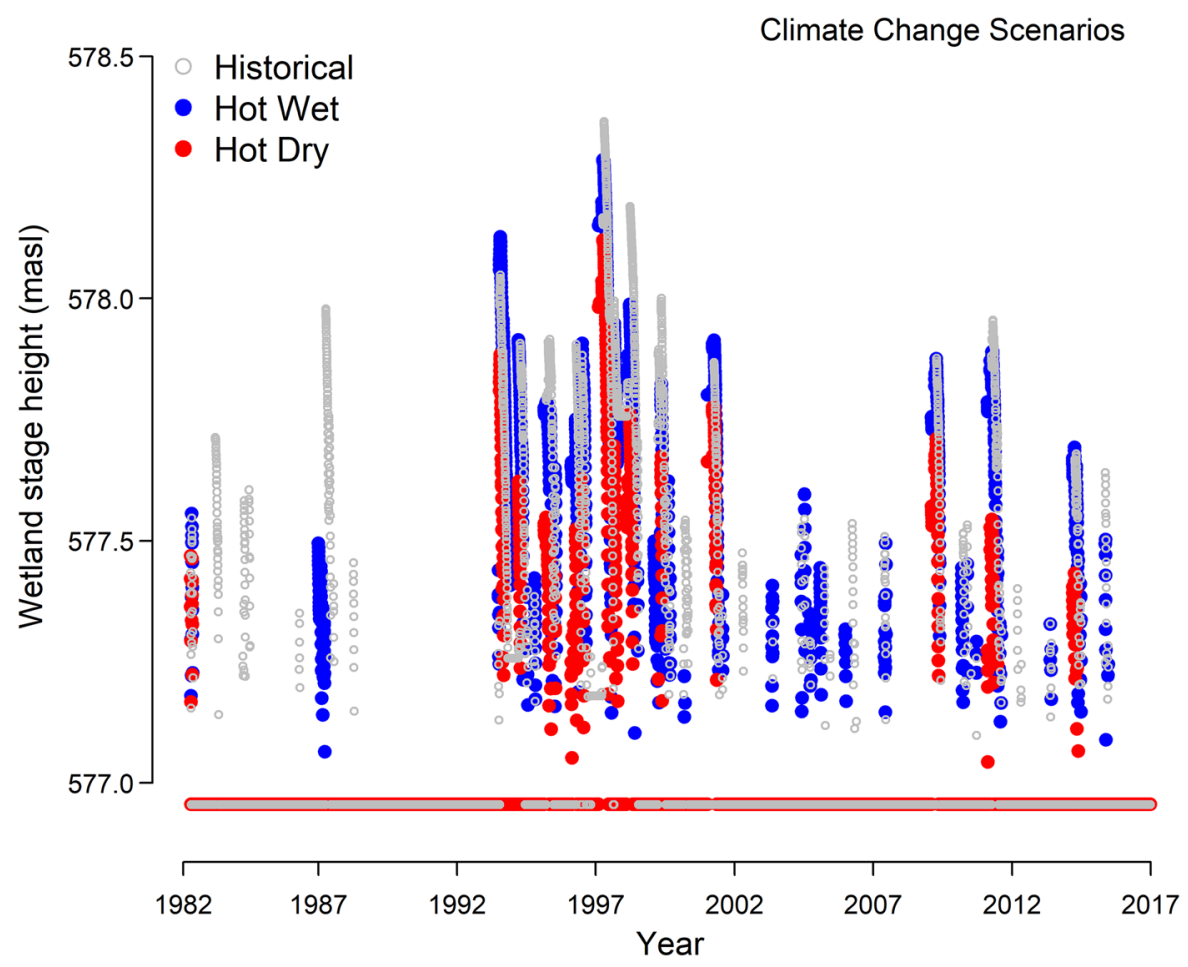

Fig. 4 Simulated water levels (meters above sea level) of Wetland T8 of the Cottonwood Lake Study Area (1982-2016) under the historical climate (gray), plus $2{ }^{\circ} \mathrm{C}$ scenario (blue), and plus $4{ }^{\circ} \mathrm{C}$ scenario (red). Wetland is completely dry at $576.95 \mathrm{~m}$ above sea level

Table 4 Modeled climate-change scenarios with no management, moderate-to-heavy grazing, and a 5-year burn interval

\begin{tabular}{|c|c|c|c|c|c|c|c|}
\hline & \multicolumn{3}{|c|}{ No management } & \multicolumn{2}{|l|}{ Grazing } & \multicolumn{2}{|c|}{ 5-year burn interval } \\
\hline & Historical & Hot dry & Hot wet & Hot dry & Hot wet & Hot dry & Hot wet \\
\hline Hydroperiod (days) & 56.21 & $\begin{array}{l}39.75 \\
(-29.3)\end{array}$ & $\begin{array}{l}60.17 \\
(+7.0)\end{array}$ & $\begin{array}{l}45.12 \\
(-19.7)\end{array}$ & $\begin{array}{l}73.92 \\
(+31.5)\end{array}$ & $\begin{array}{l}44.36 \\
(-21.1)\end{array}$ & $\begin{array}{l}64.35 \\
(+14.5)\end{array}$ \\
\hline Average water depth (m) & 0.15 & $\begin{array}{l}0.04 \\
(-73.3)\end{array}$ & $\begin{array}{l}0.10 \\
(-33.3)\end{array}$ & $\begin{array}{l}0.07 \\
(-53.3)\end{array}$ & $\begin{array}{l}0.19 \\
(+26.7)\end{array}$ & $\begin{array}{l}0.05 \\
(-66.7)\end{array}$ & $\begin{array}{l}0.15 \\
(0)\end{array}$ \\
\hline Max water depth (m) & 1.41 & $\begin{array}{l}1.17 \\
(-17)\end{array}$ & $\begin{array}{l}1.33 \\
(-5.7)\end{array}$ & $\begin{array}{l}1.23 \\
(-12.8)\end{array}$ & $\begin{array}{l}1.42 \\
(+0.7)\end{array}$ & $\begin{array}{l}1.18 \\
(-16.3)\end{array}$ & $\begin{array}{l}1.41 \\
(0)\end{array}$ \\
\hline
\end{tabular}

Values represent averages over a 35-year period from 1982 to 2016 . Numbers in parenthesis represent the percent deviation from the historical wetland T8 model

Mean May pond counts for the 35-yr period that we modeled hydrology in wetland T8 under different climate-change and land-management scenarios were lower than the historical mean value of 83,972 (Fig. 6). Under the hot wet scenario grazing resulted in the highest number of mean annual May ponds (78,884 ponds, $-6.1 \%$ change from historical mean), followed by burning $(76,316$ ponds, $-9.1 \%$ change from historical mean) and no management (71,976 ponds, $-14.3 \%$ change from historical mean). Under the hot dry scenario grazing resulted in the highest number of mean annual of May ponds $(65,097$ ponds, $-22.5 \%$ change from historical mean), followed by burning $(61,778$ ponds, $-26.4 \%$ change from historical mean) and no management $(59,966$ ponds, $-28.6 \%$ change from historical mean). 


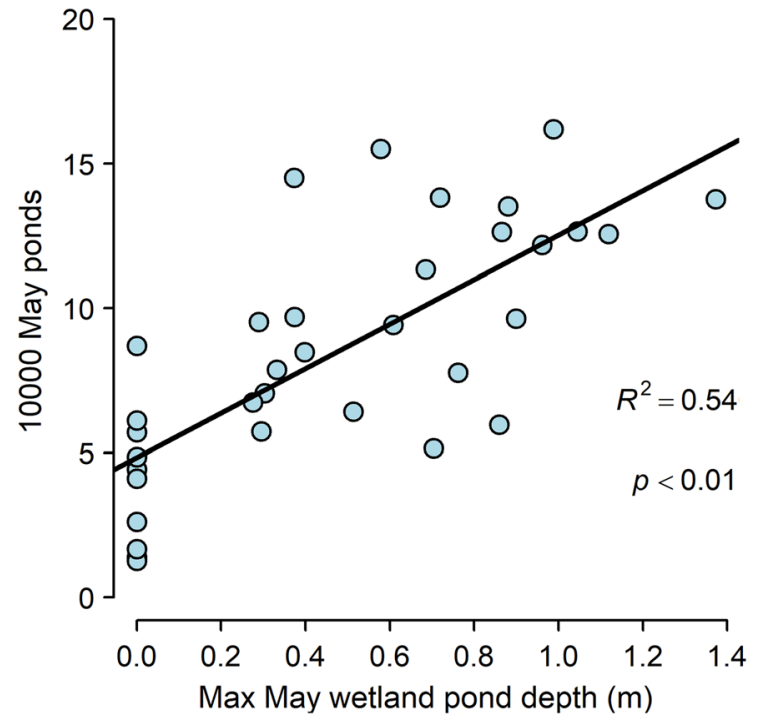

Fig. 5 Observed annual May pond count for stratum 46 and maximum May wetland pond depths in meters from 1982 to 2015. Black line represents best fit relationship

Overall, May ponds were more sensitive to change in precipitation between the hot wet scenario (Fig. 6a) and the hot dry scenario (Fig. 6b) than the introduction of any management regime.

\section{Discussion}

We found that local wetland pond duration, and the number of May ponds in wetland-dense section of North Dakota, are highly sensitive to changes in temperature, precipitation, and land management. Under hot wet and hot dry climate-change scenarios our modeling results suggested that grazing was the most effective land-management strategy to partially offset the potential pond-drying effects of climate change. However, the additional water inputs derived from grazing nor burning could completely negate the deleterious impacts of the hot dry scenario on wetland water levels.

Climate and land management can independently affect wetland hydrology, and climate change will likely impact prairie-pothole the ecohydrological functioning of wetlands. Under the hot dry scenario there would be decreases in growing season hydroperiod and ponded water depth (Table 3) as well as number of May ponds (Fig. 6) in the central portion of the PPR. Neither grazing nor burning was enough to

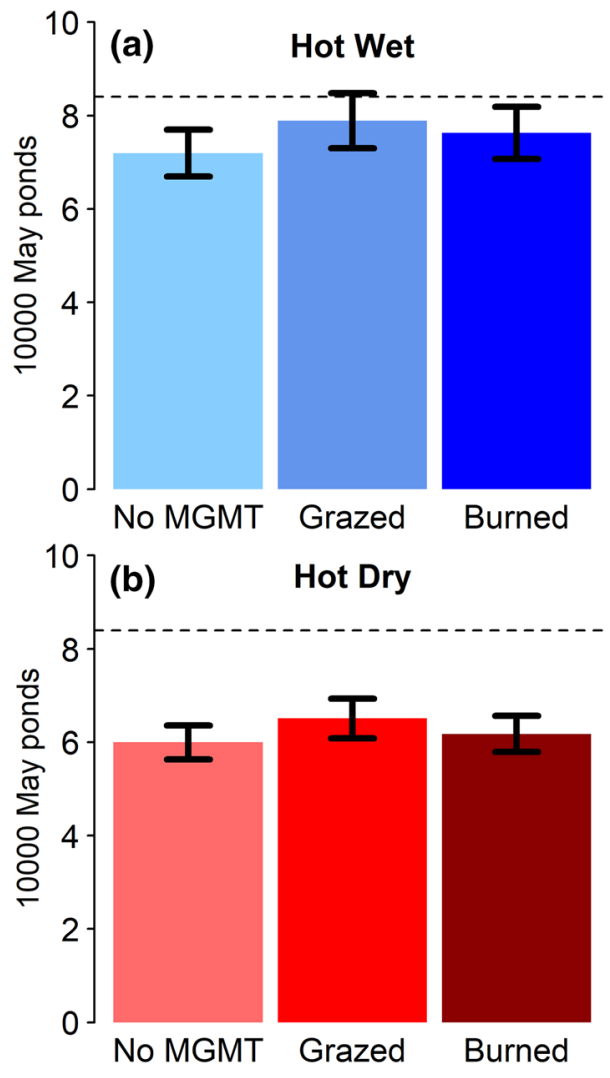

Fig. 6 May pond count estimates under climate-change and land-management (MGMT) scenarios for stratum 46. a Represents May pond count means for a 35-year period under "Hot Wet" climate-change scenario. b Represents May pond count means for a 35-year period under "Hot Dry" climate-change scenario. The dashed line represents historical mean May pond count and black bars represent standard error

negate the impacts of climate change under the hot dry scenario. Under the hot wet climate change scenario there was a distinction between overall growing season hydrological status of wetlands and the number of May ponds, which is an important time for breeding waterfowl. Although we found that growing season hydroperiod could increase under the hot wet scenario and that grazing and burning could successfully counteract losses to growing season wetland depth, the average number of May ponds decreased under all land-management scenarios.

It is important to note that these large-scale grassland grazing and burning impacts would not likely be attainable as many of the wetlands in stratum 46 are embedded within cropland and not grassland uplands (Fig. 3). Our estimates of May pond response to grazing and burning should be considered a best- 
case scenario where the maximum number of May ponds are located within un-managed grassland catchments. Although, the areas in stratum 46 with the highest density of ponds are in the Missouri Coteau, which is majority grassland-upland (Fig. 3).

Management of spatially and temporally complex systems for the benefit of a number species is inherently challenging. Upland management practices have also been shown to impact grassland-breeding species in the PPR (Kruse and Bowen 1996). Varying seasonality, frequency, and intensity of treatments has been shown to minimize the impact on grasslandbreeding birds (Kantrud 1986). These changes in May pond availability could cause problems for breeding waterfowl (Sorenson et al. 1998), amphibians (Mushet et al. 2012), and other biota with lifecycles tied to the timing of wetland ponds. Impacts to breeding ducks in the sub-region of the PPR that we studied could be much greater than areas with lower wetland densities. On average it is estimated that a comparable wetland to T8 in the same Waterfowl Breeding Population and Habitat Survey stratum contains 6-8 pairs of breeding ducks (Shaffer et al. 2019). This means that for every wetland not ponded in stratum 46 there could be displacement of 6-8 breeding duck pairs.

Despite the potential negative impacts of climate change on May ponds, grazing and burning appears to be influencing wetland hydrology dynamics throughout the growing season. Under the wet-hot scenario grazing increased the mean hydroperiod of $\mathrm{T} 8$ by almost 20 days $(+32 \%)$ and burning increased the mean hydroperiod of $\mathrm{T} 8$ by almost 10 days $(+15 \%)$ (Table 3). Grazing also increased the mean annual ponded water depth by $4 \mathrm{~cm}(+27 \%)$. These landmanagement related increases can potentially impact aquatic food webs as well as fish and amphibian life cycles (McLean et al. 2016).

Our results suggest that upland management may work as a technique to offset some of the impacts of a warmer climate on wetland hydrology. However, these techniques will only be a partial fix that will not be able to fully offset the effects of a hot dry future and will only partially offset effects of a hot wet future. In terms of snow accumulation, continuing the field observations through time would enable better model parameters that reflect the effect of management on snow across a gradient of high and low snow years. Other management strategies that could be explored would be introducing manmade or vegetative snow accumulation barriers. Snow fences have been used in other regions for increasing upland water management in rangelands (Renton et al. 2015).

Although our sensitivity analysis indicated that wetland ponding was more sensitive to changes in temperature than precipitation, further offsets may be made through increases in precipitation mean and an increase in extreme precipitation events. However, it is currently unclear how increased $\mathrm{CO}_{2}$ levels will impact precipitation regimes at a regional level. Globally, precipitation is expected to increase with higher temperatures; however these patterns vary greatly on a regional level (IPCC 2013). Currently, portions of the PPR have experienced an increase in precipitation (Millett et al. 2009), but it is unclear how those patterns will continue into the future (Ballard et al. 2014).

The effects of warming above $2{ }^{\circ} \mathrm{C}$ may be offset if changes in management and increases in precipitation do occur; however, more information will be needed on the regional effects of climate change on precipitation. The timing of precipitation will also determine the effects of climate change on breeding waterfowl. If increases in precipitation occur as larger summer storms and do not increase snow, which is the current pattern as displayed in McKenna et al. (2017), then wetlands may not be ponded during the critical May breeding period. If the PPR experiences an increase in mean annual precipitation as well as an increase in winter snow that accumulates on wet soils, our results indicate that land management could be used to increase the probability of a wetland being ponded in May.

Acknowledgements Thanks to Jack Norland and Devan McGranahan for help with editing and statistical guidance. Thanks to Neil Shook and Drew Williams for allowing access to the Woodworth Study Area and help with selecting study wetlands. Also, thanks to the US Fish and Wildlife Service Arrowwood burn crew for conducting the prescribed burns and Brandon and Lacey Koenig for supplying cattle for grazing. Thanks to Matt Solensky and his field crew, Alex Hett, Travis Strehlow, and Heather Inczauskis for help with field work Also, thanks to Kyle McLean and Eric Scherff for their modeling assistance. Thank you to Christina Hargiss for reviewing this manuscript.

Author contributions All authors contributed to the study conception and design. Material preparation, data collection and analysis were performed by OPM, and DAR. The first draft of the manuscript was written by OPM and DAR and all authors 
commented on previous versions of the manuscript. All authors read and approved the final manuscript.

Funding Funding for this research was provided by a US Geological Survey grant and cooperative agreement under the Great Plains Cooperative Ecosystem Studies Unit. Additional funding was provided by the US Geological Survey Climate Research and Development Program. We also received support from North Dakota State University's Environmental and Conservation Sciences Graduate Program. Any use of trade, firm, or product names is for descriptive purposes only and does not imply endorsement by the US government.

Data Availability The datasets generated during and/or analyzed during the current study are publicly available in the sciencebase repository, https://www.sciencebase.gov/catalog/ item/5fa1768dd34e198cb793cb60. The models used in this study are also publicly available in the sciencebase repository, https://www.sciencebase.gov/catalog/item/

5fcfed5fd34e30b91239ae7d

\section{Compliance with ethical standards}

Conflict of interest The authors declare that they have no conflict of interest/ competing interests.

Ethical approval The matter given in this manuscript is in compliance with ethical standards. The research work given in this paper does not involve human participants or animals.

Informed consent The consent to participate in this study was obtained by the authors from the authorities concerned.

Research involving animal rights This article does not contain any studies with human participants performed by any of the authors. The cattle used for grazing in this research were managed by U.S. Fish and Wildlife Service in accordance with the ethical standards.

Open Access This article is licensed under a Creative Commons Attribution 4.0 International License, which permits use, sharing, adaptation, distribution and reproduction in any medium or format, as long as you give appropriate credit to the original author(s) and the source, provide a link to the Creative Commons licence, and indicate if changes were made. The images or other third party material in this article are included in the article's Creative Commons licence, unless indicated otherwise in a credit line to the material. If material is not included in the article's Creative Commons licence and your intended use is not permitted by statutory regulation or exceeds the permitted use, you will need to obtain permission directly from the copyright holder. To view a copy of this licence, visit http://creativecommons.org/licenses/by/4.0/.

\section{References}

Ballard T, Seager R, Smerdon JE, Cook BI, Ray AJ, Rajagopalan B, Kushnir Y, Nakamura J, Henderson N (2014) Hydroclimate variability and change in the Prairie Pothole Region, the "duck factory", of North America." Earth Interact 18:1-28. https://doi.org/10.1175/EI-D-14-0004.1

Bremer DJ, Ham JM (1999) Effect of spring burning on the surface energy balance in a tallgrass prairie. Agric For Meteorol 97:43-54. https://doi.org/10.1016/S01681923(99)00034-9

Creed IF, Lane CR, Serran JN, Alexander LC, Basu NB, Calhoun AJK, Christensen JR, Cohen MJ, Craft C, D'Amico E, DeKeyser E, Fowler L, Golden HE, Jawitz JW, Kalla P, Kirkman LK, Lang M, Leibowitz SG, Lewis DB, Marton J, McLaughlin DL, Raanan-Kiperwas H, Rains MC, Rains KC, Smith L (2017) Enhancing protection for vulnerable waters. Nat Geosci 10:809. https://doi.org/10.1038/ ngeo3041

Cronshey R, McCuen R, Miller N, Rawls WJ, Robbins S, Woodward D (1986) Urban hydrology for small watersheds. TR-55

Dahl TE (2014) Status and trends of prairie wetlands in the United States 1997 to 2009.67

Gardner MJ, Altman DG (1986) Confidence-intervals rather than P-values-estimation rather than hypothesis-testing. Bmj-Brit Med J 292:746-750. https://doi.org/10.1136/bmj. 292.6522.746

Gleason RA, Laubhan MK, Euliss NH Jr (2008) Ecosystem services derived from wetland conservation practices in the United States Prairie Pothole Region with an Emphasis on the U.S. Department of Agriculture Conservation Reserve and Wetlands Reserve Programs. US Geol Surv Prof Pap 1745:1-58. https://doi.org/10.3133/pp1745

Hamon WR (1961) Estimating potential evapotranspiration. J Hydraul Div 87:107-120

Hayashi M, van der Kamp G, Rosenberry DO (2016) Hydrology of prairie wetlands: understanding the integrated surfacewater and groundwater processes. Wetlands 36:237-254. https://doi.org/10.1007/s13157-016-0797-9

Higgins KF (1989) Prescribed burning guidelines in the Northern Great Plains. vol 760. US Fish and Wildlife Service and Cooperative Extension Service, South Dakota

Huang S, Young C, Abdul-Aziz OI, Dahal D, Feng M, Liu S (2013) Simulating the water budget of a Prairie Potholes complex from LiDAR and hydrological models in North Dakota, USA. Hydrol Sci J 58:1434-1444. https://doi.org/ 10.1080/02626667.2013.831419

IPCC (2013) Climate change 2013: the physical science basis. Contribution of working group I to the fifth assessment report of the intergovernmental panel on climate change

Johnson DH (1999) The insignificance of statistical significance testing. J Wildl Manag 63:763-772. https://doi.org/10. 2307/3802789

Johnson WC, Poiani KA (2016) Climate change effects on prairie pothole wetlands: findings from a twenty-five year numerical modeling project. Wetlands 36:273-285. https:// doi.org/10.1007/s13157-016-0790-3

Johnson WC, Werner B, Guntenspergen GR, Voldseth RA, Millett B, Naugle DE, Tulbure M, Carroll RWH, Tracy J, 
Olawsky C (2010) Prairie wetland complexes as landscape functional units in a changing climate. Bioscience 60:128-140. https://doi.org/10.1525/bio.2010.60.2.7

Kantrud HA (1986) Effects of vegetation manipulation on breeding waterfowl in prairie wetlands-a literature review. Fish and Wildlife Technical Report

Kruse AD, Bowen BS (1996) Effects of grazing and burning on densities and habitats of breeding ducks in North Dakota. J Wildl Manag 60:233-246

Larson DL (1995) Effects of climate on numbers of Northern Prairie Wetlands. Clim Change 30:169-180. https://doi. org/10.1007/Bf01091840

McIntyre NE, Liu G, Gorzo J, Wright CK, Guntenspergen GR, Schwartz F (2019) Simulating the effects of climate variability on waterbodies and wetland-dependent birds in the Prairie Pothole Region. Ecosphere 10:e02711. https://doi. org/10.1002/ecs2.2711

McKenna OP, Kucia SR, Mushet DM, Anteau MJ, Wiltermuth MT (2019) Synergistic interaction of climate and land-use drivers alter the function of North American. Prairie-Pothole Wetlands Sustain 11:6581. https://doi.org/10.3390/ su11236581

McKenna OP, Mushet DM, Behrman KD, Osorio JM, Doro L (2020) Development of a novel framework for modeling field-scale conservation effects of depressional wetlands in agricultural landscapes. J Soil Water Conserv 75(6):695-703

McKenna OP, Mushet DM, Rosenberry DO, LaBaugh JW (2017) Evidence for a climate-induced ecohydrological state shift in wetland ecosystems of the southern Prairie Pothole Region. Clim Change 145:273-287. https://doi. org/10.1007/s10584-017-2097-7

McKenna OP, Mushet DM, Scherff EJ, McLean KI, Mills CT (2018) The pothole hydrology-linked systems simulator (PHyLiSS) - development and application of a systems model for prairie-pothole wetlands. US Geol Surv OpenFile Rep 1165:1-34. https://doi.org/10.3133/ofr20181165

McKenna OP, Renton DA, Mushet DM, DeKeyser ES (2020b) Vegetation and snow depth measurements in grasslands under grazing, burning, and snow fence management near Woodworth, North Dakota (2014-2016). GS ScienceBase, U.S. Geological Survey, https://doi.org/https://doi.org/10. 5066/P9VPQQAY

McLean KI, Mushet DM, Stockwell CA (2016) From "Duck Factory" to "Fish Factory": climate induced changes in vertebrate communities of prairie pothole wetlands and small lakes. Wetlands 36:407-421. https://doi.org/10. 1007/s13157-016-0766-3

Meehl GA, Tebaldi C, Nychka D (2004) Changes in frost days in simulations of twentyfirst century climate. Clim Dyn 23:495-511. https://doi.org/10.1007/s00382-004-0442-9

Menne MJ, Durre I, Vose RS, Gleason BE, Houston TG (2012) An overview of the global historical climatology networkdaily database. J Atmos Oceanic Technol 29:897-910. https://doi.org/10.1175/jtech-d-11-00103.1

Meyer MI (1985) Classification of native vegetation at the Woodworth Station, North Dakota. Prairie Nat 17:167-175

Millett B, Johnson WC, Guntenspergen G (2009) Climate trends of the North American prairie pothole region 1906-2000. Clim Change 93:243-267. https://doi.org/10.1007/s10584008-9543-5
Mushet D, Roth C, Scherff E (2017) Cottonwood lake study area-digital elevation model with topobathy: US Geological Survey Data Release.

Mushet DM, Euliss NH (2012) The Cottonwood Lake study area, a long-term wetland ecosystem monitoring site. Fact Sheet. https://doi.org/10.3133/fs20123040

Mushet DM, Euliss NH, Stockwell CA (2012) A conceptual model to facilitate amphibian conservation in the northern Great Plains. Great Plains Res 22:45-58

Mushet DM, Rosenberry DO, Euliss NH Jr, Solensky MJUS (2016) Cottonwood lake study area wetland. Data. https:// doi.org/10.5066/F7707ZJ6

Niemuth ND, Fleming KK, Reynolds RE (2014) Waterfowl conservation in the US Prairie Pothole Region: confronting the complexities of climate change. PLoS ONE 9:e100034. https://doi.org/10.1371/journal.pone.0100034

Niemuth ND, Solberg JW (2003) Response of Waterbirds to Number of Wetlands in the Prairie Pothole Region of North Dakota, U.S.A. Waterbirds 26:233-238, 236 https://doi.org/ 10.1675/1524-4695(2003)026[0233:ROWTNO]2.0.CO;2

Niemuth ND, Wangler B, Reynolds RE (2010) Spatial and temporal variation in wet area of wetlands in the Prairie Pothole Region of North Dakota and South Dakota. Wetlands 30:1053-1064. https://doi.org/10.1007/s13157-0100111-1

NOAA (2016) Climate Data Online.

Ojima D, Lackett JM (2002) Preparing for a changing climate: the potential consequences of climate variability and change: central Great Plains. Report for the U.S. Global Change Research Program, Colorado State University, 103

Omernik JM (1987) Ecoregions of the conterminous United States. Ann Assoc Am Geogr 77:118-125. https://doi.org/ 10.1111/j.1467-8306.1987.tb00149.x

Omodt HW, Johnsgard GA, Patterson DD, Olson OP (1968) The major soils of North Dakota. North Dakota Agricultural Experiment Station Bulletin 472

Palmer WC (1965) Meteorological drought. US weather bureau research paper 58

Poiani KA, Johnson WC, Swanson GA, Winter TC (1996) Climate change and northern prairie wetlands: simulations of long-term dynamics. Limnol Oceanogr 41:871-881. https://doi.org/10.4319/lo.1996.41.5.0871

R-Core-Team (2017) R: a language and environment for statistical computing. R Foundation for Statistical Computing, Vienna

Renton DA, Mushet DM, DeKeyser ES (2015) Climate change and prairie pothole wetlands: mitigating water-level and hydroperiod effects through upland management. US Geol Surv Sci Investig Rep 5004:1-32. https://doi.org/10.3133/ sir20155004

Shaffer JA, Loesch CR, Buhl DA (2019) Estimating offsets for avian displacement effects of anthropogenic impacts. Ecol Appl. https://doi.org/10.1002/eap.1983

Shook K, Pomeroy J (2012) Changes in the hydrological character of rainfall on the Canadian prairies. Hydrol Process 26:1752-1766

Smith A, Stoudt J, Gallop J (1964) Prairie pothole wetlands and marshes. In: Linduska J (ed) Waterfowl tomorrow. U.S. Government Printing Office, Washington, DC, pp 39-50

Sohl T, Dornbierer J, Wika S, Robison C (2019) Remote sensing as the foundation for high-resolution United States 
landscape projections-the land change monitoring, assessment, and projection (LCMAP) initiative. Environ Modell Softw 120:104495. https://doi.org/10.1016/j. envsoft.2019.104495

Soil Survey Staff NRCS (2016) Soil Survey Geographic (SSURGO) Database. vol 2016. http://sdmdataaccess.nrcs. usda.gov/.

Sorenson LG, Goldberg R, Root TL, Anderson MG (1998) Potential effects of global warming on waterfowl populations breeding in the Northern Great Plains. Clim Change 40:343-369. https://doi.org/10.1023/A:1005441608819

Stephens SE, Rotella JJ, Lindberg MS, Taper ML, Ringelman JK (2005) Duck nest survival in the Missouri Coteau of North Dakota: landscape effects at multiple spatial scales. Ecol Appl 15:2137-2149. https://doi.org/10.1890/04-1162

Stewart RE, Kantrud HA (1971) Classification of natural ponds and lakes in the glaciated prairie region. Resource Publication:64

USGRCP (2017) Climate science special report: fourth National Climate Assessment, vol I. Global Change Research Program, Washington, DC. https://doi.org/10.7930/J0J964J6

Voldseth RA, Johnson WC, Gilmanov T, Guntenspergen GR, Millett BV (2007) Model estimation of land-use effects on water levels of northern prairie wetlands. Ecol Appl 17:527-540. https://doi.org/10.1890/05-1195

Voldseth RA, Johnson WC, Guntenspergen GR, Gilmanov T, Millett BV (2009) Adaptation of farming practices could buffer effects of climate change on northern prairie wetlands. Wetlands 29:635-647. https://doi.org/10.1672/ 07-241.1

Williams SH, Austin JE (2014) Legacy data for a northern prairie grassland-Woodworth Study Area, North Dakota. U.S. Geological Survey Open-File Report 2014-1188:85

Winter TC (2003) Hydrological, chemical, and biological characteristics of a prairie pothole wetland complex under highly variable climate conditions: the Cottonwood Lake area, east-central North Dakota. US Geol Surv Prof Pap 1675:1-109. https://doi.org/10.3133/pp1675

Winter TC, Rosenberry DO (1998) Hydrology of prairie pothole wetlands during drought and deluge: A 17-year study of the cottonwood lake wetland complex in North Dakota in the perspective of longer term measured and proxy hydrological records. Clim Change 40:189-209

Yochum SE, Norman J (2015) Wildfire-induced flooding and erosion-potential modeling: examples from Colorado, 2012 and 2013. In: Proceedings of the 3 rd joint federal interagency conference on sedimentation and hydrologic modeling, 2015. pp 953-964

Zhou Q, Tollerud HJ, Barber CP, Smith K, Zelenak D (2020) Training data selection for annual land cover classification for the land change monitoring, assessment, and projection (LCMAP) initiative. Remote Sens 12:699

Publisher's Note Springer Nature remains neutral with regard to jurisdictional claims in published maps and institutional affiliations. 